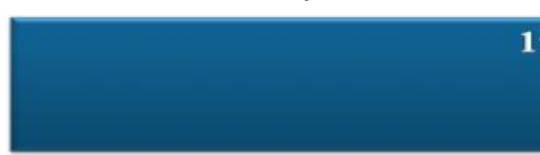

ISSN: 2717-736X

Cilt: 2 Sayı: 2
19 MAYIS JOURNAL OF SOCLAL SCIENCES

19 MAYIS SOSY AL BILIMLER DERGISİ

\title{
The Impact of Poverty and Education on Female Child Marriage in Afghanistan: Evidence from 2015 Afghanistan Demographic and Health Survey
}

\section{Hamayon Ehsan}

Associated Professor, Balkh University, Economic Faculty Afghanistan: hamayonehsan2018@gmail.com OrcID: 0000-0001-8549-5505

\section{Sayed Osman Akrami}

Professor, Balkh University, Economic Faculty, Afghanistan: s.osman.akrami@gmail.com

$$
\text { OrcID: 0000-0001-5587-1194 }
$$

\section{Noorulhaq Ghafoori}

Associated Professor, Balkh University, Economic Faculty, Afghanistan: ghafoori202@gmail.com OrcID: 0000-0001-8471-8375

\begin{abstract}
Female children as the most vulnerable part of Afghan society extremely influencing by the lack of education facilities and poverty. Child marriage as a human right violation, destroying the child's future and affecting the health of society. Despite; implementation of several programs in the level of nation and international to decrease the female child marriage, still Afghanistan has the highest female child marriage in the region. In this research, the data from 2015 Afghanistan Demographic and Health Survey (2015AfDHS) has extracted to gauge the impact of poverty and education on female child marriage in Afghanistan. To examine the effect of poverty and education on female child marriage binary logistic regression was applied. The result shows, poverty and education strongly influencing the female child marriage. Girls who live in poor household 1.18 times more likely to marry and who ever not attended to school 1.16 times more likely to marry in the age of 10-19 years. Similarly; female child illiteracy, living in rural area, ethnicity and region also significantly increasing the female child marriage in Afghanistan. In conclusion, poverty is directly affecting the household status and increasing the female child marriage in Afghanistan. By creating job opportunities to job seekers, improving the households condition, providing the equal accessible and qualified education facilities to all female children the probability of female child marriage significantly will decrease.
\end{abstract}

Key words: Poverty, Education, Female Child Marriage, Afghanistan. 


\section{Introduction}

Afghanistan as a poorest country, almost with 40 years' civil war and international terrorism still struggling with many different socioeconomic challenges. Poverty, insecurity, unemployment, inequality, traditional convenance, exchanged marriages, gender imbalance, disqualified education, lack of schools, illiteracy, lack of law enforcement and religious believes are the main socioeconomic factors that influencing Afghan children lives. The most vulnerable part of Afghan society is children; the main victims of four decades' war were children too. Drug addiction, forcing to labor market, pediatric, nutrition, violence, enrolling to terrorist groups, disability, mortality, sexual harassments and child marriage are the major problems of Afghan children. Around 40.9\% of afghan population is under 14 years' age, and by the median age of 19 years Afghanistan become one of the youngest population in the world (CIA, 2018). Despite remarkable efforts on women and children protection and empowerment since stablishing of government after Taliban regime in 2001, still the vulnerable part of society (children) extremely fighting with many difficulties and forcing to marry in childhood age.

Furthermore, early child marriage affecting the lives of children and taking them off from school and education, the most of marriage engaging by without permission of children especially female child in Afghanistan. Child marriage is defined as a marriage of a girl or boy before the age of 18 and refers to both formal marriages and informal unions in which children under the age of 18 live with a partner as if married (UNICEF, 2016). Globally, more than 14 million girls marry each year in the age of less than 18 years, over 750 million women alive today were married as children more than $50 \%$ of them live in South Asia, India has higher number of marry at childhood period in the global and Afghanistan, having by more than one in three women married in the age of 18 is coming in second rank in the region (UNFPA, UNICEF, 2016).

Almost $75 \%$ of Afghan society live in rural (CSO, MoPH, DHS, 2017). Rural residence influencing the child marriage in Afghanistan because of lack of school, illiterate households head and parents, traditional culture, poverty, religion believes and lack of awareness about consequences of early marriage. Urban residents are much more likely to have completed secondary school than rural residents in Afghanistan. Among women in urban households, $10 \%$ have completed secondary school, as compared with $2 \%$ of women in rural households. Similarly, $19 \%$ of men in urban areas have completed secondary school, compared with $8 \%$ of men in rural areas (CSO, MoPH, DHS, 2017). literacy rate in female adult is $17.6 \%$ and male is 45.4\% (USAID, 2011). Dropping school strongly associated with sex and place of residence area, among females, $30 \%$ dropped out because, their parents did not send them to school, while $19 \%$ dropped out because they got married (CSO, MoPH, DHS, 2017). Share of Afghan children in labor market is $21.4 \%$, and in early child marriage is $30 \%$ (UNDP, 2018)

Poverty is extremely influencing the female child marriage in Afghanistan, According to, Afghan Multidimensional poverty index (MPI) the poverty ratio in 2016-2017 reported by 51.7\% (NSIA, UNICEF, 2019), the GDP per capita in 2018 reported 550\$ (WORLDBANK, 2019). The rate of poverty rapidly changing rural to urban, the urban poverty rate is $18.1 \%$, whereas the rural rate is $61.1 \%$ (NSIA, UNICEF, 2019). Poverty rate is rapidly changing province to province, poor people live across the different provinces in Afghanistan. More than 
$25 \%$ of poor people live in four provinces such as: Herat is home to nearly $8 \%$ of poor people in the country, followed by Nangarhar 7\%, Kandahar6\%, and Kunduz 6\% (NSIA, UNICEF, OPHI, 2016). In 2017 from 8.478 million active labor force almost $24 \%$ of youth age of 15-24 years were jobless (CIA, 2018). Since 2001 after terrorist attack till to 2019 in the intervening 18 years, the United States has costed approximately nearly $\$ 750$ billion for military and approximately $\$ 133$ billion for reconstruction (CRS, 2019). Despite of all efforts, majority of population suffering from shortage of jobs, clean drinking water, shortage of housing, poverty, children mortality, gender inequality, international terrorism, insecurity, weak governance and early child marriage.

In strict religious households like Afghanistan; female children and women not allowed to go out of their homes for study and work with male together in same place, in addition of religion traditional culture, poverty and many other factors strongly improving the female child marriage in Afghanistan. The consequences of early female child marriage in afghanistan will be caused to taking out children from school and education, increase the sexual disease, poor health for mother and baby, increase the risk of maternal and children mortalities, pregnancy death, nutrition problems, weak newborn baby, pediatric disease, domestic violence, murder, suicide, divorce, dependence, and escape from home.

Child marriages are illegal in all develop and many under develop countries based on children protection laws. Afghanistan government has not official children protection law before year of 2019, the Afghanistan government officially started implementing of children protection law and rights after printing on official gazette on 11 march 2019. According to this law, girls or boys under age of 18 deemed as children (UNICEF, 2019). Related to current research in Afghanistan, there is no enough empirical evidence to explain the association of female child marriage and household's socioeconomic characteristic and predict the consequences of early female child marriage, gap of empirical study exists in Afghan academic society. In this study we conducted to find the impact of household poverty, girl's education level, ethnicity, residency area, and reading newspaper and magazine on female child marriage in Afghanistan.

\section{Background}

This research paper highly ties with household's poverty condition and effect of household socioeconomic status on female early child marriage in Afghanistan. In 1989 world leaders came together and promised to children to protect them fulfil rights, they separated the childhood from adulthood, until 18 years recognized as childhood period (UN, Convention on the rights of the child, 1989).Child marriage is most common in low income countries and is mentionable that, in the poorest households are often occurred, and child marriage has strong association with economic status of households. Family with shortage of financial sources and pressure of poverty often forcing their female child to marry, child marriage is a global problem that cuts across countries, cultures, and religions. According to Sustainable Development Goals (SDGs), Around 750 million women and girls alive today were married as children and 150 million more girls will be married by 2030 because of poverty, food insecurity, lack of education, gender inequality, less economic growth, human rights violations and injustice (UN, 
Sustainable Development Goals, 2019), ending child marriage is part of the sustainable development goals.

The consequence of child marriage in northern Ghana resulted with poor health, increased the child mortality and low agency for women (Richard de Groot, Maxwell Yiryele Kuunyem, Tia Palermo, 2018). A research in Africa conducted that, early child marriage driven by poverty and increased risk for sexually transmitted diseases, cervical cancer, malaria, death during childbirth, obstetric fistulas, increased risk for premature birth and death as neonates, infants and children (Nour, 2006). Afghanistan as poorer country, $76 \%$ of deliveries take place in the pregnant mother's home in rural area and usually with no proper medical assistance, only $46 \%$ of children age 12-23 months received all basic vaccines (CSO, MoPH, DHS, 2017), the most of early child marriage resulted by pregnancy death in afghanistan because of delivery conditions. Early child marriage strongly effecting the future life of children, girls who marry in early age more likely to be poor and remain poor.

Attending to school has significant association by female early child marriage. girls in district level of India, with no education and primary education more likely to marry at an early age, girls with secondary education the early marriage starts declination and higher level of education extremely decreased the probability of an early female child marriage, similarly girls who lives in poorest households more likely to marry at early age than who lives in richest households (PintuPaul, 2019). The early child marriage in poorest households effect the child future and the children still remain poor, the childhood poverty effect the future of child by getting lower earnings and worse job in labor market (Lesner, 2018). Family structure effects the economic future of children, female head, family size and household demographic characteristics effect the child poverty. Children whose lived in female headed family the child poverty is constant and whose mother is participated in simulated marriage the poverty rate is significantly decreased (Adam Thomas, Isabel Sawhill, 2002).

Economic reforms and urbanization policies influencing the wellbeing of children. China 1979 economic reform accelerated the trend of urbanization and influenced investment in children. The prior characteristics of households has been changed after china 1979 economic reform and significantly associated with children school attainment (Gordon Anderson, Teng Wah Leo, 2009).Early marriage is strongly associated with poverty, low educational attainment, and rural residence in less income countries. Increasing knowledge among families and communities about the benefits of delaying early marriage can lead to greater educational achievement for all, lower fertility, increased life expectancy for women, and benefits to children's health and education. Political will, aligned with effective programs and policies, will enable millions of adolescent females and their families to reach their potential (Rafael Cortez, Jennifer Yarger, Mara Decker, Claire Brindis, 2015). Early child marriage has psychological, health and education risk especially for female child. The cost of child marriage for health, education, and well-being much higher for girls whose marry at an early child age (Minh Cong Nguyen, Quentin Wodon, 2012).Early female child marriage is not confined only in Afghanistan, it is worlds challenge and rapidly increasing. Marrying of prepubescent girls with adult men is very common in low income countries. 
Socioeconomic and cultural status of households influencing early female child marriage in addition of poverty in Ghana (Babatunde Ahonsi, Kamil Fuseini , Dela Nai2, Erika Goldson, Selina Owusu, Ismail Ndifuna, Icilda Humes, Placide L. Tapsoba, 2019), according to authors, girls never attainted to school more likely to marry in child age. People who participated to religious activities have similar advantage who has not religious, religion and marriage have positive effect on life mechanism (Linda J. Waite, Evelyn L. Lehrer, 2004). In most of low income countries, the marriage decision often will be taken by child parents without the permission of girls. In Hindu religion marriage, girls have no right to object and mostly Hindu girls married by the decision of their parents (Kaydani, 2016). Across the world, different figures in child marriage behavior are associated with different economic challenges and opportunities.

\section{Research methodology}

Lack of reliable empirical evidences on influencing factors of female child marriage in Afghanistan, this study has been designed by extracting the 2015 AfDHS data to present up to date information about exact impact of household's economic status and children school attendance on female early child marriage in Afghanistan.

\subsection{Data information}

In this research the 2015 Afghanistan Demographic and Health Survey (AfDHS 2015) data has been used by getting the official permission letter from DHS program. The (AfDHS 2015) project funded by United States Agency for International Development (USAID) and implemented by central statistics organization (CSO) and ministry of public health (MoPH) of Afghanistan in the time period of June 15, 2015, to February 23, 2016 (CSO, MoPH, DHS, 2017). The (AfDHS 2015) project objectives were provide up to date information on family planning, fertility levels, marriage, fertility preferences, child feeding practices, nutritional status of children and women, childhood mortality, maternal and child health, awareness and attitudes regarding HIV/AIDS, knowledge about other illnesses and domestic violence (CSO, MoPH, DHS, 2017). Using by multi-stage sampling method a total of 950 sample points (clusters) 260 from urban and 690 from rural area were selected from all 7 regions (34 provinces). In the second stage from each selected clusters a fix number of 27 households selected by the equal probability systematic selection process, totally 25,650 households were included to this survey (CSO, MoPH, DHS, 2017). In (AfDHS 2015) project three types of questionnaire were used namely: The Household Questionnaire, the Woman's Questionnaire, and the Man's Questionnaire (CSO, MoPH, DHS, 2017). In the women's questionnaire all evermarried women age 10-49 in the selected households has been interviewed by $98 \%$ response rate.

\subsection{Variable information}

Women marry four times earlier than men in Afghanistan, the median age of first marriage for women is 18.5 years and for men is 22.9 years (CSO, MoPH, DHS, 2017). Table 1 explain the variable of this research. The outcome variable was all ever married women and 
have been asked about them age at first birth, age of all ever married women divided to three age categories, such as; age at first birth between 10-15 years' age coded (10-15) =1 otherwise $=0$, age at first between 16-19 year-old coded $(16-19=1$ otherwise $=0)$ and age at first birth between $10-19$ years old coded $(10-19=1$ otherwise $=0)$. The explanatory variables of this research were all women ever attended or not attended to school, the literacy level of women measured by reading newspapers and magazine frequently in a week, household wealth index measured by household owner equity and assets, residency area, ethnicity and region of ever married women. Ever school attended coded yes $=1$ otherwise $=0$, frequently reading the newspapers and magazine coded as yes $=1$ otherwise $=0$. household wealth index combined as rich and richest household categories to rich, poor and poorest households to poor. The rich household category coded $($ Rich + Richest $)=1$, Middle $=2$ and $($ Poor + Poorest $)=3$. Afghanistan as a multiethnicity country, ethnicity of ever married women coded as Pashtun=1, Tajik=2, Hazara $=3$, Uzbek $=4$, Turkmen $=5$, Nuristani $=6$, Baloch $=7$, Pashai $=8$ and Other $=9$. Afghanistan divided into seven administrative regions and coded as Central=1, Northwest=2, Northeast=3, Eastern $=4$, Western $=5$, Southeast $=6$ and Southwest $=7$.

Table 1: Variable explanation

\begin{tabular}{|c|c|c|c|}
\hline Variables & Description & \multicolumn{2}{|c|}{ Measurements } \\
\hline \multicolumn{4}{|l|}{ Age at first birth } \\
\hline Between 10-15 age & Ever married women age at first birth & $10-15=1$ & Otherwise $=0$ \\
\hline Between 16-19 age & Ever married women age at first birth & $16-19=1$ & Otherwise $=0$ \\
\hline Between 10-19 age & Ever married women age at first birth & $10-19=1$ & Otherwise $=0$ \\
\hline Ever School Attended & Ever married women school attended & Yes $=1$ & $\mathrm{No}=0$ \\
\hline Newspaper and magazine & Frequent of reading newspaper and magazine & Yes $=1$ & $\mathrm{No}=0$ \\
\hline Household wealth index & \multicolumn{3}{|c|}{ Wealth coded into 3 categories $($ Poor + Poorest $)=3$, Middle $=2,($ Rich + Richest $)=1$} \\
\hline Residency area & The residency of respondents coded as a & Rural $=1$ & Urban $=0$ \\
\hline Ethnicity & \multicolumn{3}{|c|}{ Ethnicity of respondents coded from 1 to 9 base on population majority } \\
\hline Region & \multicolumn{3}{|c|}{ Region of participants coded from 1 to 7 base on central to other 6 regions } \\
\hline
\end{tabular}

source: research findings

\subsection{Statistical analysis}

To examine the impact of household poverty and girl's education on female child marriage in different age of prepuberty period in Afghanistan, frequency tabulation was used to describe the characteristics of research variables. Using by frequency tables we described the prevalence of female child marriage in different ethnicity group and region, then we approached that the poverty and illiteracy expanded among to all seven regions and all ethnicities group. The binary logistic regression model was applied to this research. The outcome variable of first model presents the marriage age between 10-15 years, the second model present the marriage age between 16-19 years and the third model illustrates the marriage age between 10-19 years. Household poverty and girls school attendance were the control variables and residency area, frequent of reading newspapers and magazine, group ethnicity and living region were noncontrollable variables.

The binary logistic regression equation for all three models are as bellow: 


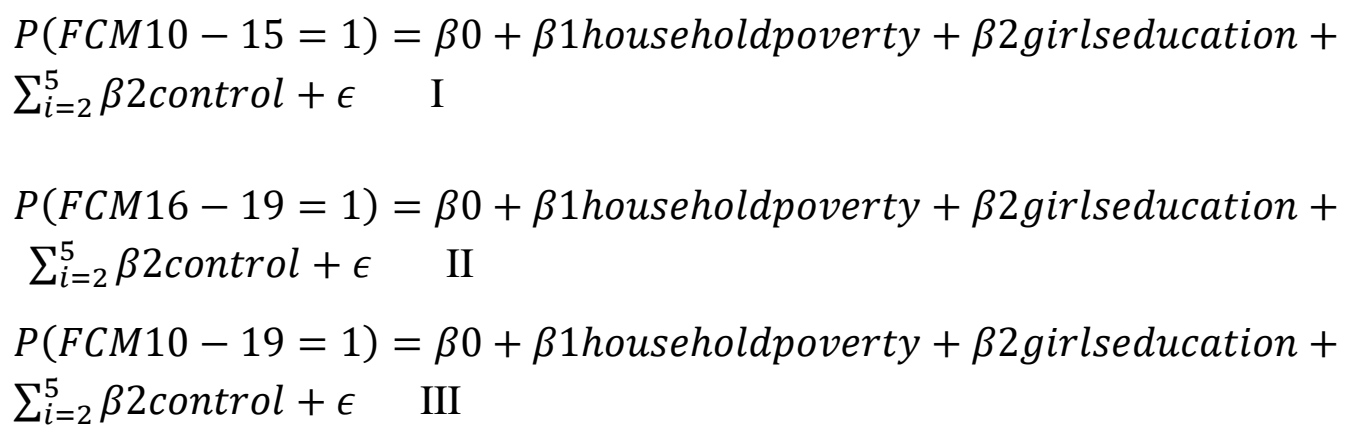

In model I, P(FCM10-15) denotes the probability of female child marriage in the age of 10-15, in model II P(FCM16-19) present the probability of female child marriage in the age of 16-19 years and in model III P(FCM-10-19) illustrates the probability of female child marriage in the age of 10-19 years. $\beta 0$ represents the intercept of models and $\beta 1$ and $\beta 2$ shows the slope (effect) of household poverty and girls education on female child marriage between age of 1019 years in Afghanistan.

\section{Result}

Table 3 illustrates distribution of female child marriage among the group ethnicity in Afghanistan. The percentage of female child marriage in Baloch ethnicity by $67 \%$ and Turkmen ethnicity by $44 \%$ was the highest and lowest rank in all ethnicity of Afghanistan. Tajik ethnicity by $63 \%$ reported as a second ethnicity in female child marriage and Hazara by $61 \%$, Uzbek by $61 \%$, Pashai by $60 \%$ and Pashtun by $58 \%$ listed in female child marriage, average female child marriage in whole ethnicity was $60 \%$. It means $60 \%$ of female marriage in Afghanistan occurred in teenager childhood period. Female ever school attendant in Tajik and Uzbek ethnicity by $15 \%$ and Nuristani ethnicity by $2 \%$ was the highest and lowest between all ethnicities. Female school attendant in Pashtun was 6\%, in Hazara 10\%, in Turkmen 7\%, in Baloch $10 \%$, Pashai $4 \%$ and other ethnicity $10 \%$. Around the country only $10 \%$ of married women ever enrolled to school. In the case of rural residency Nuristani by $99 \%$ and Uzbek by $65 \%$ was the highest and lowest ethnicity. $76 \%$ of Pashtun respondents, $69 \%$ of Tajik, $81 \%$ Hazara, $89 \%$ of Turkmen, 84\% of Baloch, 93\% of Pashai and $67 \%$ of other ethnicity respondents live in rural area, in whole Afghanistan $75 \%$ of all participants lives in rural. The average of reading newspapers and magazine between ever married women who are participated to this survey was $3 \%$ in whole countryside. Among $5 \%$ of Tajik ever married women read newspaper, Pashtun by $2 \%$, Hazara and Uzbek by $3 \%$, Turkmen, Baloch and Pashai by $1 \%$ and Nuristani by $0.5 \%$ recorded in reading newspaper and magazine list.

Economic condition of households effecting the female child marriage in Afghanistan. DHS wealth index calculated based on household assets and services by categorizing items and separating into dichotomous indicator variables and continuous variables (Shea O.Rutstein, 2008). In this study the five category of wealth index coded into three categories of poor, middle and rich households. Nuristani ethnicity by $32 \%$ and Hazara by $11 \%$ listed as highest and 
lowest ethnicity in middle household category, Pashtun ethnicity by $40 \%$ and Pashai by $15 \%$ was the highest and lowest ethnicity in poor household list. The average of rich, middle and poor index in whole Afghan households has been calculated by 43\%, 22\% and 35\%. In other words, the majority of Afghan households lives in below of rich index.

Table 2 : Cross-tabulation and frequency distribution of research variables based on major ethnicity in Afghanistan evidence from 2015 AfDHS data

\begin{tabular}{|c|c|c|c|c|c|c|c|c|c|c|}
\hline \multirow{2}{*}{ Variables } & \multicolumn{10}{|c|}{ Ethnicity } \\
\hline & Pashtun & Tajik & Hazara & Uzbek & Turkmen & Nuristani & Baloch & Pashai & Other & Total \\
\hline \multicolumn{11}{|l|}{ Age at first birth } \\
\hline$\leq 19$ age $(\%)$ & $30,450(58)$ & $24,951(63)$ & $6,964(61)$ & $5,423(61)$ & $1,197(44)$ & $3,172(60)$ & $1,029(67)$ & $1,419(60)$ & $1,174(61)$ & $75,779(60)$ \\
\hline$\geq 20$ age & 21,932 & 14,393 & 4,314 & 3,368 & 1,490 & 2,065 & 491 & 925 & 731 & 49,709 \\
\hline Total & 52,382 & 39,344 & 11,278 & 8,791 & 2,687 & 5,237 & 1,520 & 2,344 & 1,905 & 125,488 \\
\hline Ever School Att. (No) & 49,481 & 33,128 & 10,042 & 7,408 & 2,484 & 5,103 & 1,366 & 2,251 & 1,712 & 112,975 \\
\hline Yes $(\%)$ & $2,901(6)$ & $6,216(15)$ & $1,236(10)$ & $1,383(15)$ & $203(7)$ & $134(2)$ & 154(10) & $93(4)$ & 193(10) & $12,513(10)$ \\
\hline Total & 52,382 & 39,344 & 11,278 & 8,791 & 2,687 & 5,237 & 1,520 & 2,344 & 1,905 & 125,488 \\
\hline Residence (Urban) & 12,171 & 11,870 & 2,133 & 3,054 & 274 & 4 & 235 & 142 & 622 & 30,505 \\
\hline Rural (\%) & $40,211(76)$ & $27,474(69)$ & $9,145(81)$ & $5,737(65)$ & $2,413(89)$ & $5,233(99)$ & $1,285(84)$ & $2,202(93)$ & $1,283(67)$ & $94,983(75)$ \\
\hline Total & 52,382 & 39,344 & 11,278 & 8,791 & 2,687 & $\mathbf{5 , 2 3 7}$ & 1,520 & 2,344 & 1,905 & 125,488 \\
\hline Newspaper Yes(\%) & $921(2)$ & $2,023(5)$ & $303(3)$ & $251(3)$ & $37(1)$ & $25(0.5)$ & $18(1)$ & $34(1)$ & $48(1)$ & $3,660(3)$ \\
\hline No & 51,364 & 37,214 & 10,959 & 8,537 & 2,650 & 5,210 & 1,497 & 2,308 & 1,857 & 121,596 \\
\hline Total & 52,285 & 39,237 & 11,262 & $\mathbf{8 , 7 8 8}$ & 2,687 & 5,235 & 1,515 & 2,342 & 1,905 & 125,256 \\
\hline Wealth Index (Rich) & 17,741 & 17,366 & 7,805 & 4,216 & 1,720 & 2,523 & 697 & 1,397 & 1,017 & 54,482 \\
\hline Middle(\%) & $13,986(27)$ & $6,802(17)$ & 1,192(11) & $1,456(17)$ & $506(18)$ & $1,669(32)$ & 295(19) & $594(25)$ & $266(14)$ & $26,766(22)$ \\
\hline Poor $(\%)$ & $20,655(40)$ & $15,176(38)$ & $2,281(20)$ & $3,119(35)$ & 461(17) & $1,045(20)$ & $528(35)$ & $353(15)$ & $622(32)$ & $44,240(35)$ \\
\hline Total & 52,382 & 39,344 & 11,278 & 8,791 & 2,687 & 5,237 & 1,520 & 2,344 & 1,905 & 125,488 \\
\hline
\end{tabular}

Source: Research findings

The median age at first birth among women between 15-49 years is 20.1 years in Afghanistan (CSO, MoPH, DHS, 2017). As in Table 3 tabulated, Around the $60 \%$ of women in Afghanistan had first birth before age of 20 years, it means $60 \%$ of female marriage occurred in teenager live period. According to regional division, southeast region by $47 \%$ and (northeast, southwest) by $67 \%$ is the lowest and highest region at female child marriage in Afghanistan. In accessibility of female children to equal education right, uneducated parents, religious, unequal education opportunity in all region, weak governance, corruption, poverty, conflict and war are the mean reasons that most of female children marrying before age of 20 years in Afghanistan.

Table 3: Cross-tabulation and frequency distribution of female child marriage among the seven region of Afghanistan based on 2015 AfDHS survey data

\begin{tabular}{c|cccccccc}
\hline \multirow{2}{*}{ variable } & \multicolumn{7}{|c}{ region } \\
\cline { 2 - 8 } & Central & Northwest & Northeast & Eastern & Western & Southeast & Southwest & Total \\
\hline $\begin{array}{c}\text { Age at first birth } \\
\leq 19 \text { age (\%) }\end{array}$ & & & & & & & & \\
& $11,282(52)$ & $9,765(57)$ & $9,610(67)$ & $11,048(62)$ & $14,075(72)$ & $8,296(47)$ & $11,814(67)$ & $75,890(60)$
\end{tabular}




\begin{tabular}{l|cccccccc}
$\geq 20$ age & 10,339 & 7,413 & 4,650 & 6,899 & 5,356 & 9,243 & 5,925 & 49,825 \\
Total & $\mathbf{2 1 , 6 2 1}$ & $\mathbf{1 7 , 1 7 8}$ & $\mathbf{1 4 , 2 6 0}$ & $\mathbf{1 7 , 9 4 7}$ & $\mathbf{1 9 , 4 3 1}$ & $\mathbf{1 7 , 5 3 9}$ & $\mathbf{1 7 , 7 3 9}$ & $\mathbf{1 2 5 , 7 1 5}$ \\
\hline
\end{tabular}

Source: research findings

To examine the exact effect of child marriage drivers on afghan female children, we separated the female child marriage age, as early child marriage between age of 10-15 years, age of 15-19 years and age of 10-19 years. Table 4 indicates the effect of child marriage drivers in Afghanistan in different child marriage age. As in Table 4 illustrated, living in rural area significantly effecting the child marriage age, female child who lives in rural area 1.32 times more likely to marry in the age of 10-15 years old than urban residence, in the case of age between 16-19 years old, female children who lives in rural area 0.90 times less likely to marry than urban area, generally rural residence girls in the age of 10-19 years more likely to marry by the odd ratio of 1.06 and confidence interval of $95 \%$ than urban residence. We concluded that, female child in prepuberty age more effecting by rural residency, when female children growing to puberty age the rural risk of marriage significantly decreasing.

Lack of enough school and disqualified education services strongly effecting the future of children in afghanistan, school attendance and literacy directly effecting the female child marriage. Girls who does not attended to school would not be able to read newspaper, magazine, books and improve her awareness, education strongly influencing the female child marriage, girls who does not attended to school rather than who attended to school 1.18 times more likely to marry in the age of 10-15, 1.25 times in the age of 16-19 and 1.16 times in the age of 10-19 years' old by confidence interval of $95 \%$. In addition of not attended to school, children who do not read books, newspapers and magazine 1.73 times by confidence interval of $95 \%$ more likely to marry in the age of 10-15 years than who read books and increase her awareness and knowledge, 1.25 times more likely marry in the age of 16-19 and 1.60 times more likely to marry in the age of 10-19 years. School attendance and reading newspapers, magazines, books and attending to education centers strongly decreasing the early female child marriage in Afghanistan. The effect of not reading books was higher than not attended to school.

Poverty as a main challenge of the low income countries causing many social difficulties. Afghanistan as a low income country by the GDP per capita of 550\$ in 2018 (WORLDBANK, 2019), and poverty rate of 51.7\% (NSIA, UNICEF, 2019) extremely effecting the female early child marriage. Female children of poor households 1.10 times more likely to marry in the age of 10-15 years than rich households, female children of middle households 0.93 times less likely to marry in the age of 10-15 years than children of rich households. Poor household's children in the age of 16-19 years 1.12 times more likely to marry rather than rich household's female children, girls who lives in poor households in the age of 10-19 years, 1.18 times more likely to marry than who lives in rich households by confidence interval of 95\%. Poverty significantly increasing an early child marriage in Afghanistan.

Afghanistan as a multiethnicity country, more than 15 major ethnics live together (CIA, 2018). Pashtun, Tajik, Hazara and Uzbek have the major population of afghanistan, according to this research the average of female child marriage in Turkmen ethnicity was less than all other ethnicities, based on Turkmen ethnicity female child except of Nuristani ethnicity other 
are more likely to marry in the age of prepuberty period. Baloch by odd ratio of 2.86 and Hazara by 2.44 were the highest in the ethnicities rather than Turkmen child marriage, it means Baloch girls in the age of 10-15, 2.86 times and Hazara girls 2.44 times more likely to marry than Turkmen girls. After Baloch and Hazara, Tajik girls 2.06 times, Uzbeks 1.96 times, Pashtuns 1.56 times, Pasha's 1.33 times and remained ethnics 1.57 times more likely to marry in the age of 10-15 years than Turkmen girls, only Nuristani girls 0.29 times less likely to marry in the age of 10-15 years than Turkmen girls in same age. In model 2, the odd ratio of all ethnicities expect Nuristani ethnicity, significantly increased rather than Model 1 odd ratios, it means in the age of 16-19 the effect of all ethnicities rather than Turkmen ethnicity highly decreased, but girls of Nuristani in the age 16-19 than Turkmen girls 2.13 times more likely to marry and has the highest ratio between all other ethnicities. In model 3, female child marriage of all ethnicities in the age of 10-19 years than Turkmen female child, conducted at least more than 1.54 times for each ethnicity. In other word, female children of Turkmen ethnicity at least 1.54 times less likely to marry in the age of 10-19 years than all other ethnics.

Poverty separates in all seven region of Afghanistan, and average of female child marriage approximately were same in all regions, southeast region by $47 \%$ was the minimum female child marriage between the all seven regions. Based on southeast region, western region by 2.23 and southwest by 2.14 odd ratio were the highest female under 15 years old than southeast region. Female children of northeast region by 1.92 , eastern region by 1.69 , northwest region by 1.29 and central region by 1.19 odd ratio more likely to marry in the age of 10-15 years than female children of southeast region with $95 \%$ confidence interval. Western region residence child girls than other regions more likely to marry in the age of 15-19 years. As in Model 2 revealed, the western region girls 1.80 times more likely to marry in the age of 15-19 years than based region because of high poverty rate between all region (NSIA, UNICEF, 2019), the central region child girls marriage in the age of 16-19 years was the lowest rate in the region based on southeast region girls by 1.07 odd ratio, it means the central region girls 1.07 times more likely to marry in the age of 16-19 years than southeast girls in the age of 1619 years. The result of Model III presents that, the children between 10-19 years in all region than based region at least 1.11 times more likely to marry. Western region by 2.77 , southwest by 2.18 , northeast by 2.10 , eastern by 1.76 , northwest by 1.41 and central by 1.11 odd ratios has been listed. The confidence interval in all three models were $95 \%$.

Table 4 : Binary Logistic Regression Result for Female Child Marriage Between Age of (10-19) in Afghanistan Based on 2015 Afghanistan Demographic and Health Survey

\begin{tabular}{cccc}
\hline \multirow{4}{*}{ Variables } & Model (I) & Model(II) & Model(III) \\
\cline { 2 - 4 } & $\begin{array}{c}\text { Marriage Between 10-15 } \\
\text { Age }(\mathrm{n}=17,850) \\
\text { Odd Ratio(95\%CI) }\end{array}$ & $\begin{array}{c}\text { Marriage Between 16-19 } \\
\text { Age }(\mathrm{n}=58,020) \\
\text { Odd Ratio(95\%CI) }\end{array}$ & $\begin{array}{c}\text { Marriage Between 10-19 } \\
\text { Age }(\mathrm{n}=75,890) \\
\text { Odd Ratio(95\%CI) }\end{array}$ \\
\hline $\begin{array}{c}\text { Residency (Urban) } \\
\text { Rural }\end{array}$ & $1.32 *(1.59-1.97)$ & $0.90 *(0.87-0.9)$ & $1.06 *(1.02-1.10)$ \\
\hline
\end{tabular}




\begin{tabular}{c|ccc}
\hline $\begin{array}{c}\text { Newspaper(read) } \\
\text { Not }\end{array}$ & $1.73 *(1.53-1.97)$ & $1.23 * 91.14-1.33)$ & $1.60 *(1.48-1.73)$ \\
\hline School (Attended) & & & \\
Not & $1.18 *(0.79-0.89)$ & $1.25 *(1.19-1.30)$ & $1.16 *(1.11-1.21)$ \\
\hline Wealth Index (Rich) & & & \\
Middle & $0.93 *(0.89-0.97)$ & $0.99(0.96-1.02)$ & $0.97(0.94-1.00)$ \\
Poor & $1.10 *(1.03-1.13)$ & $1.12 * 91.08-1.15)$ & $1.18 *(1.14-1.22)$ \\
\hline Ethnicity (Turkmen) & & & \\
Pashtun & $1.56 *(1.32-1.87)$ & $1.38^{*}\{1.26-1.51)$ & $1.54 *(1.40-1.68)$ \\
Tajik & $2.06 *(1.76-2.42)$ & $1.41 *(1.29-1.54)$ & $1.83 *(1.68-1.99)$ \\
Hazara & $2.44 *(2.07-2.87)$ & $1.17 *(1.06-1.28)$ & $1.66 *(1.51-1.82)$ \\
Uzbek & $1.96 *(1.67-2.30)$ & $1.41 *(1.29-1.54$ & $1.76 *(1.61-1.93)$ \\
Nuristani & $0.29 *(0.22-0.36)$ & $2.13 *(1.90-2.38)$ & $1.59 *(1.43-1.78)$ \\
Baloch & $2.86 *(2.34-3.49)$ & $1.02(0.89-1.17)$ & $1.69 *(1.46-1.94)$ \\
Pashai & $1.33 *(1.07-1.64)$ & $1.75 *(1.56-1.99)$ & $1.88 *(1.66-2.13)$ \\
Other & $1.57 *(1.28-1.93)$ & $1.45^{*}(1.31-1.67)$ & $1.67 *(1.48-1.88)$ \\
\hline Region (Southeast) & & & \\
Central & $1.19 *(1.11-1.28)$ & $1.07 * 91.02-1.12)$ & $1.11 *(1.07-1.17)$ \\
Northwest & $1.29 *(1.18-1.40)$ & $1.32 *(1.25-1.39)$ & $1.41 *(1.34-1.49)$ \\
Northeast & $1.92 *(1.80-2.10)$ & $1.54 *(1.47-1.62)$ & $2.10 *(2.00-2.22)$ \\
Eastern & $1.69 *(1.57-1.83)$ & $1.43 *(1.36-1.50)$ & $1.76 *(1.68-1.85)$ \\
Western & $2.23 *(2.08-2.39)$ & $1.80 *(1.72-1.88)$ & $2.77 *(2.64-2.90)$ \\
Southwest & $2.14 *(2.01-2.29)$ & $1.52 *(1.46-1.59)$ & $2.18 *(2.08-2.28)$ \\
\hline Source & &
\end{tabular}

Source: Research Findings

$* \mathrm{p}<0.05$

\section{Conclusion}

Early female child marriage in Afghanistan highly increasing by the effecting of child marriage drivers. Our result conducted that, more than $75 \%$ of households living in the rural area suffering by poverty. female school attendance rate was $10 \%$, frequency of reading newspapers and books in households' female member were 3\%, more than $35 \%$ of households calculated as a poor, $22 \%$ as a middle and $43 \%$ as a rich. This research revealed, poverty and girl's education significantly effecting the Afghan female child marriage, girls who live in poor households the probability of marrying in the age of teenager were more than girls who lives in middle or rich households. Education of female child also strongly influencing the marriage of them in prepuberty age, female child who never attended to school more likely to marry in childhood age than who attended. In addition of poverty and girl's education, reading not newspapers, magazine, books and attending to education centers, living in rural area, ethnicities and region strongly increasing the female child marriage in Afghanistan. because of most of urban residents and partial of rural residents have not equal access to schools, electricity power, public education centers, enough books, newspapers and magazines. uneducated parents, believes, cultures and lack of awareness about the consequences of early child marriage extremely effecting the live of Afghan female child. The research result suggested, by 
increasing the quantity and quality of schools and education centers in rural area the probability of early female child marriage significantly will be decrease in the long term, in addition of equal qualified education to all children, giving job opportunity to all and improving the economic condition of poor households extremely will reduce the early female child marriage.

\section{References}

Adam Thomas , Isabel Sawhill. (2002). For richer or for poorer: Marriage as an antipoverty strategy. Journal of Policy Analysis and Management, 21(4), 587-599. doi: https://doi.org/10.1002/pam.10075

Babatunde Ahonsi, Kamil Fuseini, Dela Nai2, Erika Goldson, Selina Owusu, Ismail Ndifuna, Icilda Humes, Placide L. Tapsoba. (2019). Child marriage in Ghana: evidence from a multi-method study. BMC Women's Health, 19(126), 1-15. doi:https://doi.org/10.1186/s12905-019-0823-1

Children Protection Law: Afghanistan. (2019). Retrieved from https://www.unicef.org/afghanistan/media/3931/file/Law\%20on\%20Protection\%2 0of\%20Child\%20Rights\%20Dari\%20and\%20Pashto.pdf\%20.pdf

CIA. (2018). The World Factbook:Afghanistan. Retrieved 12 19, 2019, from https://www.cia.gov/library/publications/the-world-factbook/geos/af.html

CRS. (2019). Afghanistan: Background and U.S. Policy. washington DC: Congressional Research Service. Retrieved from https://crsreports.congress.gov/product/pdf/R/R45818

CSO, MoPH, DHS. (2017). AFGHANISTAN DEMOGRAPHIC AND HEALTH SURVEY 2015. $\begin{array}{llll}\text { Retrieved } & 12 & 15, & \text { from }\end{array}$ file://C:/Users/DELL/Desktop/Mortality\%20rate/mortality/female\%20marriage/ DHS\%20final\%20Report\%20Afhanitan.pdf

Gordon Anderson, Teng Wah Leo. (2009). CHILDREN IN URBAN CHINA AFTER THE ONE CHILD POLICY. The Review on Income and Wealth, 55(s1), 607-629. doi: https://doi.org/10.1111/j.1475-4991.2009.00333.x

Kaydani, M. (2016). Raising Awareness for Gender Equality in Hindu Marriage. European Journal of Multidisciplinary Studies, 1(6), 51-55. doi: http://dx.doi.org/10.26417/ejms.v3i1.p50-54

Lesner, R. V. (2018). The long-term effect of childhood poverty. J Popul Econ, 31, 969-1004. doi:https://doi.org/10.1007/s00148-017-0674-8

Linda J. Waite , Evelyn L. Lehrer. (2004). The Benefits from Marriage and Religion in the United States: A Comparative Analysis. Population and Development Review, 29(2), 255-275. doi: https://doi.org/10.1111/j.1728-4457.2003.00255.x 
Minh Cong Nguyen, Quentin Wodon. (2012). Measuring Child Marriage. Economics Bulletin, 32(1), 398-411. $\quad$ Retrieved $12 \quad 22, \quad 2019$, from http://www.accessecon.com/Pubs/EB/2012/Volume32/EB-12-V32-I1-P36.pdf

Nour, N. M. (2006, November). Health Consequences of Child Marriage in Africa. Emerg Infect Dis, 12(11), 1644-1649. doi:https://www.ncbi.nlm.nih.gov/pmc/articles/PMC3372345/

NSIA, UNICEF. (2019). Afghanistan Multidimensional Poverty Index 2016-2017 :Report and $\begin{array}{lllll}\text { Analysis. } & \text { Retrieved } & 212 & 2019, & \text { from }\end{array}$ https://www.unicef.org/afghanistan/media/3811/file/AFG_2019_vs9_(online).pdf $\% 20 . p d f$

NSIA, UNICEF, OPHI. (2016). Poverty in Afghanistan. Retrieved from https://www.adb.org/countries/afghanistan/poverty

PintuPaul. (2019, May). Effects of education and poverty on the prevalence of girl child marriage in India: A district-level analysis. Children and Youth Services Review, 100, 16-21. doi:https://doi.org/10.1016/j.childyouth.2019.02.033

Rafael Cortez, Jennifer Yarger, Mara Decker, Claire Brindis. (2015). SOCIOECONOMIC DIFFERENCES IN ADOLESCENT SEXUAL AND REPRODUCTIVE HEALTH: MARRIAGE. Washington Dc: World Bank: Health, Nutrition and Population Global Practice. Retrieved $12 \quad 22, \quad 2019$, from http://documents.worldbank.org/curated/en/936451468165567019/pdf/935420RE VISED00iage0JAN-26-150FINAL.pdf

Richard de Groot, Maxwell Yiryele Kuunyem, Tia Palermo. (2018, Feb 26). Child marriage and associated outcomes in northern Ghana: a cross-sectional study. BMC Public Health, 18(285). doi:doi: 10.1186/s12889-018-5166-6

Shea O.Rutstein. (2008). The DHS Wealth Index: Approaches for Rural and Urban Areas. Demographic and Health Research. Retrieved 12 18, 2019, from https://www.dhsprogram.com/pubs/pdf/WP60/WP60.pdf

UN. (1989). Convention on the rights of the child. New York: United Nation. Retrieved 12 21, 2019, from https://www.unicef.org/child-rights-convention/what-is-the-convention

UN. (2019). Sustainable Development Goals. New York: United Naion. Retrieved from https://www.un.org/sustainabledevelopment/gender-equality/

UNDP. (2018). Human Development Report: Afghanistan. New York: United Nation Development Program. Retrieved from https://www.af.undp.org/content/afghanistan/en/home/countryinfo.html

UNFPA, UNICEF. (2016). Mapping of CHILD MARRIAGE INITIATIVES in South Asia. Retrieved 12 19, 2019, from https://asiapacific.unfpa.org/sites/default/files/pubpdf/FINALMapping\%20of\%20Child\%20Marriage\%20Initiatives\%20in\%20South $\% 20$ Asia\%281\%29.pdf 
UNICEF. (2016). Summary of a Baseline Study to Estimate the Number of Child Marriages in South Asia 2014-2017. Retrieved from https://www.unicef.org/rosa/media/1991/file

USAID. (2011). Adult literacy rate, population 15+ years: Afghanistan. Retrieved from https://idea.usaid.gov/cd/afghanistan/gender

WORLD BANK. (2019). Country Porfile: Afghanistan. Retrieved 12 20, 2019, from https://data.worldbank.org/country/afghanistan 